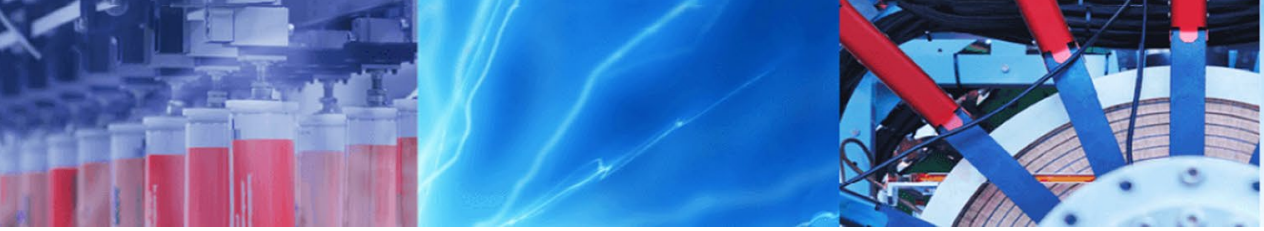

Research Article

\title{
Precipitation and temperature response to sea salt injection into low marine clouds over West Africa
}

\author{
Mojisola O. Adeniyi ${ }^{1}$ [D $\cdot$ Blessing E. I. Bassey ${ }^{1}$
}

Received: 4 April 2020 / Accepted: 16 February 2021 / Published online: 25 February 2021

(c) The Author(s) 2021 OPEN

\begin{abstract}
Sea salt injection into the tropical marine clouds is evaluated for its potentials to reduce the negative impact of the prevailing global warming over West Africa. Radiative forcing is determined as the intercept of the regression of response of radiation parameter to that of surface air temperature. The seasonal responses of temperature and precipitation to geoengineering over West Africa are analysed using temperature and precipitation outputs from IPSL-M5A-LR with three different forcing scenarios. The three scenarios are historical greenhouse gas concentrations, Representative Concentration Pathway $4.5 \mathrm{~W} / \mathrm{m}^{2}$ scenario (RCP4.5) and combination of RCP4.5 and geoengineering forcing (sea salt climate engineering, G5). 20-year means in the middle of G5 (2045-2064) are considered for the future period, and the historical climatology from 1986 to 2005 is used. Net downward flux and top of atmosphere outgoing shortwave radiation have negative forcing only at the western Sahel. The G5 reduces the warming in the RCP4.5 scenario over the whole of West Africa. It also shifts ITCZ northward with respect to RCP4.5, thereby increasing wetness over most of the land areas. The areas with wetness response have anomalous westerly with respect to RCP 4.5 and latitudinal location below anomalous easterly wind. Results show that G5 is effective in reducing the RCP4.5 projected warming up to $1.2 \mathrm{~K}$ and increasing wetness over most land areas. The $\mathrm{G} 5$ has a damaging effect on the temperature pattern at the southern ocean and coastal areas, while it has damaging effect on precipitation patterns at some parts of the Sahel.
\end{abstract}

Keywords G5 · West Africa · Geoengineering · Effectiveness · Climate changes

\section{Introduction}

Global warming is a planetary problem felt on local scales that will be around for years to come. Regardless of the increasing awareness of global warming, greenhouse gases are continuously being emitted all over the world and are causing series of unparalleled environmental issues [1]. Such environmental issues include rising sea levels and more frequent and severe heat waves, drought and flooding, to mention a few [1]. African countries are being highly affected by global change regardless of the fact that Africa contributes the least to global warming [2].
Africa has been greatly impacted by the changes in temperature [2]. Large parts of Southern Africa and Sahel have observed a decrease in rainfall, while Central Africa has seen an increase in rainfall [2]. Shifting precipitation patterns, rising temperatures and increased extreme events are already being experienced in West Africa. Over the last fifty years, West Africa temperatures have increased, in line with an increase in global temperatures [2]. It has also been observed that over the past fifty years, frequency in extreme rainfall has increased and is likely to continue to increase in the future [3]. Adeniyi [4] reported that, as a result of 4.5 and $8.5 \mathrm{Wm}^{-2}$ radiative forcing,

Supplementary Information The online version contains supplementary material available at https://doi.org/10.1007/s42452-021-04388 $-9$.

Mojisola O. Adeniyi, mojisolaadeniyi@yahoo.com | 'Department of Physics, University of Ibadan, Ibadan, Nigeria. 
significantly wetter climate, delayed and false precipitation onset should be expected at eastern Sahel, Western West Africa and Central Guinea Coast, respectively, over West Africa. These expected changes in climate would impact the productivity of the poor West African farmers who practice subsistence farming $[4,5]$. West Africans are already battling with desertification that has claimed part of the Sahel, loss of river discharge capacity [6] and flooding which has affected people who have their livelihood very close to river basins [7].

Alongside mitigation and adaptation, geoengineering or climate engineering, a term that describes the intentional modification of earth's climate system has also been considered as a strategy in counteracting global warming and stopping surface temperature from increasing above $2 \mathrm{~K}$ from preindustrial times. This has been done in two major ways which are carbon dioxide removal and solar radiation management (SRM), which has a high chance of counteracting global warming. The SRM aims at adjusting amount of solar irradiance reaching or absorbed by the earth's surface, so as to modify earth's radiation balance between incoming shortwave and outgoing longwave radiations. One such method of solar geoengineering is marine cloud brightening (MCB) in which sea salt is injected into low marine clouds. This is achieved by spraying seawater in the marine atmosphere within $30^{\circ} \mathrm{N}$ and $30^{\circ} \mathrm{S}[8,9]$ with the use of unmanned vessels, when the seawater evaporates it leaves the sea salt in the atmosphere, the sea salt can then serve as cloud condensation nuclei (CCN), which increases the concentration of the cloud droplet number (but reduced droplet size), total surface area and the albedo of the cloud. These consequently brighten the marine stratocumulus clouds and enhance reflection of solar radiation in clear sky condition. Reduction in cloud droplets size can also suppress condensation/ precipitation and extend the lifetime and optical depth of cloud [10].

The Geoengineering Model Intercomparison Project (GeoMIP, [11]) was created to better understand the spread and agreement of climate models on the response of the global climate to solar geoengineering. Among the GeoMIP experiments, there is the $\mathrm{G} 3$ experiment which is combined with RCP4.5 forcing, starting in 2020 with gradual ramp-up of the amount of $\mathrm{SO}_{2}$ or sulphate aerosol injected. It was designed to keep the top of atmosphere radiative flux at 2020 levels against RCP4.5 through stratospheric sulphate aerosol injection. The sea salt climate engineering (SSCE) is a computational model experiment based on $\mathrm{MCB}$, which was designed to simulate solar radiation and low clouds response to sea salt particles. The SSCE experiment was designed to counteract the globally averaged RCP4.5 radiative forcing and keep the top of atmosphere radiative forcing to 2020 level for 50 years $[8,9,12]$. The $G 5$ experiment is not one of the core GeoMIP experiments [13]. It has identical set-up as G3 but uses SSCE into the marine low clouds. The RCP4.5 scenario is a stabilization scenario in which the total radiative forcing at $4.5 \mathrm{~W} / \mathrm{m}^{2}$ (approximately $650 \mathrm{ppm}$ carbon dioxide equivalent) is stabilized shortly after 2100 without over shooting the long-run radiative forcing target level [14-16].

Alterskjaer et al. [8] carried out the first coordinated multimodel study of SSCE; they used three earth system models, namely Institute Pierre Simon Laplace ESM (IPSL-CM5A), Norwegian ESM (NorESM) and Max Planck Institute ESM (MPI-ESM) to investigate the SSCE simulation. Their results revealed that a strong enough application of SSCE could cancel the warming projected in RCP4.5 scenario. The IPSLCM5A is equipped with diagnostic CNDC but depends on sea salt concentration climatology. The simulated variations in sea salt from sea salt injection in the NorESM were used as input in the IPSL-CM5A and were added to its sea salt climatology. The resulting sea salt variations then effect changes in the diagnostic CNDC and the cloud properties. The annual strength of SSCE found for IPSL-CM5A [8] was used to determine the sea salt injection, sea salt concentration variations and CDNC variations. The IPSL-CM5A does not resolve the effect of sea salt injection on cloud condensation [10]. This makes cloud brightening in the IPSL-CM5A less effective, and higher sea salt concentration is required to achieve a target radiative forcing. The model is also relatively less sensitive to variations in aerosol concentration as a result of its relatively larger aerosol background concentration [8].

The aim of this paper is to understand the effects of G5 sea salt climate engineering on precipitation and temperature patterns over West African countries. This is achieved with the use of the only (singular) model that participated in G5 GeoMIP experiment. In this study, precipitation and near-surface air temperature simulations from low-resolution IPSL-CM5A-LR for Representative Concentration Pathway 4.5 (RCP4.5) W/m² scenario from 2020 to 2064, solar radiation management scheme G5 (sea salt climate engineering) from 2020 to 2064 and historical climatology from 1986 to 2005 are considered over the West African region during the wet (April to October) and dry (November to March) seasons. The historical climatology is taken as the last 20 years in the historical simulation from IPSLCM5A-LR. The study area is shown in Fig. 1 (longitudes19:19E; latitudes-0:29N).

\section{Model description and method}

\subsection{Model description}

The IPSL-CM5A-LR is the low-resolution $\left(1.9^{\circ} \times 3.75^{\circ}\right)$ version of the IPSL-CM5. The IPSL-CM5 is a coupled model 


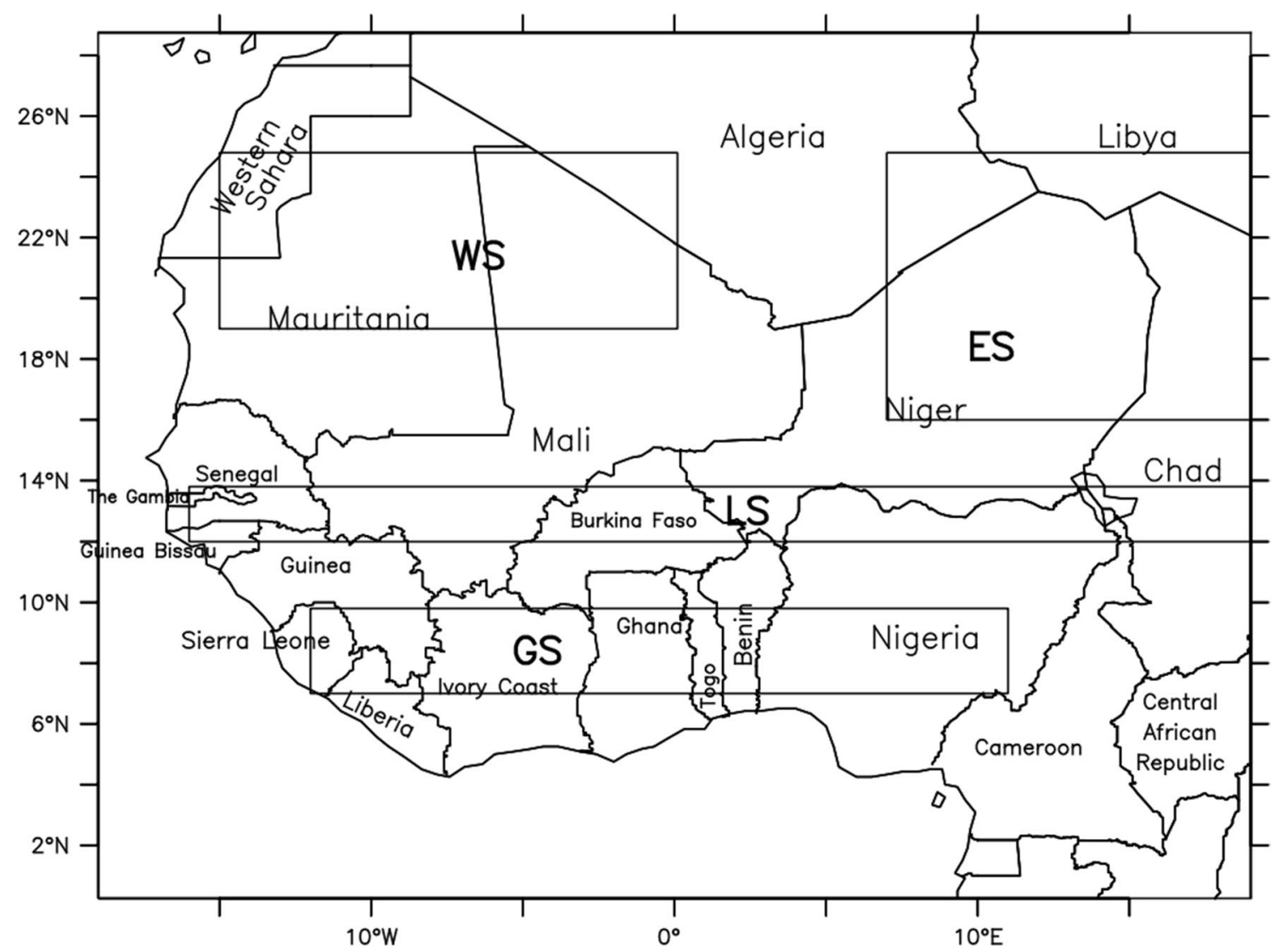

Fig. 1 Countries and temperature regions in which G5 is evaluated. WS represents western Sahel, ES stands for eastern Sahel, LS is lower Sahel, while GS is Guinea Savannah

that combines the atmosphere, land surface, ocean and sea ice components [17] for earth system modelling. The IPSL-CM5A-LR uses the Laboratoire de Météorologie Dynamiqe Model with Zoom Capability (LMDZ) atmospheric general circulation model [18] and the ORganizing Carbon and Hydrology In Dynamic Ecosystems Environment (ORCHIDE) land surface model [19] on horizontal grid resolution of $3.6^{\circ} \times 1.8^{\circ}$ and 39 vertical levels. The oceanic component of IPSL-CM5A-LR is NEMOversion 3.2 [20], which includes the Louvain-la-Neuve sea Ice Model (LIM; [21]) and the marine biogeochemistry model Pelagic Interactions Scheme for Carbon and Ecosystem Studies (PISCES, [22]). The Nucleus for European Modelling of the Ocean (NEMO) version 3.2 is on horizontal resolution of $2^{\circ}-0.5^{\circ}$ with 31 vertical levels. Variable horizontal resolutions are available in NEMO, so the horizontal resolution is refined at the tropics by $0.5^{\circ}$, while $2^{\circ}$ is used over other ocean areas [17]. The land carbon component, ORCHIDE [19], includes phenology for 13 different plant functional types. The ocean carbon component is PISCES [22]. The simulation output from this model can be found at: https://esgf-node.IInl.gov/ search/cmip5/.
The historical precipitation and temperature simulations from IPSL-CM5A-LR are not far from the multimodel means of Coupled Model Intercomparison Project Phase 5 (CMIP5) over West Africa [4, 23, 24]. Globally and over the Tibetian Plateau, IPSL-CM5A-LR simulates climate variables closer to observation than the multimodel ensemble. The model has biases in general but it is the only available model with $G 5$ experiment, since $G 5$ is not one of the core GeoMIP experiments [13].

\subsection{Method}

Radiative forcing for $\mathrm{G} 5$ is determined using the Gregory et al. [25] regression method. The difference between G5 and RCP4.5 is calculated for the top of atmosphere radiative fluxes (net downward radiative flux: RTMT; shortwave clearsky radiative flux: RSUTCS, shortwave radiative flux: RSUT; longwave clearsky radiative flux: RLUTCS; longwave radiative flux: RLUT; and net clearsky radiative flux: NETCS) and $2 \mathrm{~m}$ temperature. The differences obtained for each of the components of radiative fluxes are individually regressed against the difference obtained for temperature. The analysis is done based on the temperature regions of 
West Africa (Fig. 1). This is done over the first 40 years to allow for substantial temperature reduction.

The effective radiative forcing is taken as intercept, while the feedback parameter is the slope of the regression line [26].

In this study, the GeoMIP G5 experiment follows the SSCE protocol in Alterskjaer et al. [8] and the SALT experiment in IMPLICC [9]. The SSCE was switched on and off, respectively, for the first 50 years and the last 20 years of the simulation. The spatial analysis is carried out for the period 2045-2064 that falls within the SSCE to determine the response of climate to $\mathrm{G} 5$ over West Africa. The outputs of RCP 4.5 are considered for the same period. The period 1986-2005 is chosen to represent the historical climatology. All data from the GeoMIP G5, RCP4.5 scenario and historical climatology are divided into two seasons, namely dry (November-March) and wet (April-October) season.

The temperature and precipitation outputs of the RCP4.5 and historical climatology experiments are compared to determine the projected changes in temperature and precipitation. A similar analysis is conducted for the $\mathrm{G} 5$ and RCP4.5 experiments to determine the effect of G5 on the RCP4.5 scenario; finally, the G5 is compared to the historical climatology to determine the potential and effectiveness of $\mathrm{G} 5$ in reducing temperature back to historical times over West Africa.

\subsubsection{RCP 4.5 scenario-historical climatology (no geoengineering)}

The historical simulation for the near-surface air temperature and precipitation is compared to that in the RCP4.5 scenario for the period 2045-2064 by finding the difference between RCP 4.5 scenario mean and the historical climatological mean. To determine the significance of the obtained difference/change, this difference is expressed in number of standard deviations in the historical simulation by dividing the difference with the standard deviation in the historical climatology $[26,27]$. The obtained value is then multiplied by $\sqrt{ } 2$ to test the significance of the difference between the two means. Statistical significance is measured at the 5\% significance level, using two standard deviations as an approximation of the critical value for a two-tailed $t$ test $[26,27]$. The formulae used in these analyses are given below:

Ave change $=$ RCP 4.5 ave - HIST ave

Variability $=\frac{\text { RCP } 4.5 \text { ave }- \text { HIST ave }}{\text { HIST STD }}$

where Ave = average, $\mathrm{HIST}=$ historical and STD $=$ standard deviation.

\subsubsection{GeoMIP G5-RCP 4.5 scenario}

The projected influence of GeoMIP G5 on RCP 4.5 scenario for the near-surface air temperature and precipitation is analysed by finding the difference between their average in RCP 4.5 scenario and their average in GeoMIP G5 in the period 2045-2064. The precipitation data are also analysed by finding the percentage difference between the RCP4.5 scenario and the GeoMIP G5 experiment. The formulae used for these analyses are given as Eqs. 3 and 4. The statistical significance of a change in temperature or precipitation is found by comparison with internal variability. The internal variability is estimated by calculating the standard deviation of nonoverlapping 20-year means from the last 500 years of a 1000 -year preindustrial control run $[26,27]$. This captures the low-frequency climate variability, and the 20-year means give sufficient mean values up to 25 to constrain the uncertainty of the calculated standard deviations. To test the significance of the difference between two means, the internal variability is multiplied by $\sqrt{2}$. Statistical significance is measured at the $5 \%$ significance level, using two standard deviations as an approximation of the critical value for a two-tailed $t$ test.

Ave change_G5 = G5 ave - RCP4.5 ave

Percentage change $=\frac{\mathrm{G} 5 \text { ave }-\mathrm{RCP} 4.5 \text { ave }}{\mathrm{RCP} 4.5 \text { ave }} \times 100$

Variability_PiCtrl $=\frac{\mathrm{G} 5 \text { ave }- \text { RCP4.5 ave }}{\text { PiCtrlSTD }}$

where $\mathrm{PiCtrl}=$ preindustrial control and PiCtrISTD = stand ard deviation in the preindustrial control.

\subsubsection{GeoMIP G5—historical climatology (effectiveness)}

The historical data for the near-surface air temperature and precipitation are compared to that in the GeoMIP G5 experiment for the period 2045-2064 by finding the difference between GeoMIP mean and the historical mean, and these differences are also expressed in number of standard deviation of the historical data by dividing their difference with the standard deviation of the historical climatology following Crook et al. [26]. Equation 6 is used for this analysis.

Variability_Hist $=\frac{\text { G5 ave }- \text { HIST ave }}{\text { HIST STD }}$

To understand the effectiveness of G5, a framework suggested in Crook et al. [27] is used, in which response 
to geoengineering is divided into three categories in terms of number of standard deviations:

1. "Effective: the climate variable has been brought within \pm 2 standard deviations (SD20) from the historical mean"

2. "Marginal effective: the climate variable has been brought closer to the historical mean than RCP4.5 but is outside \pm 2 standard deviations of the historical mean"

3. "Damaging: the climate variable is further away from the historical mean (either positive or negative) than RCP 4.5"

\section{Results}

\subsection{Radiative forcing}

Top of atmosphere net downward flux and top of atmosphere outgoing shortwave radiation have negative forcing only at the western Sahel (WS), but have positive forcing at the other temperature regions of West Africa. The WS is closer to the ocean, where the sea salt injection is applied, than the other temperature regions, and that is why the G5 shows the expected effect of net downward radiation reduction there.

Top of atmosphere outgoing shortwave clear sky radiation (direct effect) generally has negative forcing over all the temperature regions of West Africa. The clear sky outgoing longwave radiation has no forcing at the WS, but negative forcing at other temperature regions. TOA outgoing longwave radiation exhibits radiative forcing in opposite direction to its shortwave counterpart as expected. Net clear sky radiation has negative radiative forcing (Fig. 2).

\subsection{No geoengineering}

In this section, the impacts of anthropogenic forcing at the medium level (RCP4.5) on temperature and precipitation patterns and how much temperature and precipitation patterns have been affected by it with respect to historical time are presented.

\subsubsection{Near-Surface Air Temperature (No Geoengineering) Projection}

In the dry season, warming is projected by the RCP 4.5 scenario all over West Africa when compared to the historical climatology (Fig. 3a). Sahel $\left(12-25^{\circ} \mathrm{N}\right)$ would have the highest warming. Warming in most countries in the domain falls within 2 standard deviations of the 1986-2005 climatology apart from the coastal areas (southern Nigeria, southern Benin, southern Togo, southern Cameroon, southern Ivory Coast, Sierra Leone and southern Liberia), where warming is above 2 standard deviations of the 1986-2005 climatology (Fig. 3e, f) depicting significant warming.

Wide spread warming is projected over West Africa during the wet season by the RCP 4.5 scenario when compared to the 1986-2005 climatology. The greatest warming is projected between 14 and $29^{\circ} \mathrm{N}$ (Fig. 3b). Warming in almost half of the land area in the domain falls within 2 standard deviations of the 1986-2005 temperature climatology. However, significant
Fig. 2 Radiative forcing over the temperature regions of West Africa

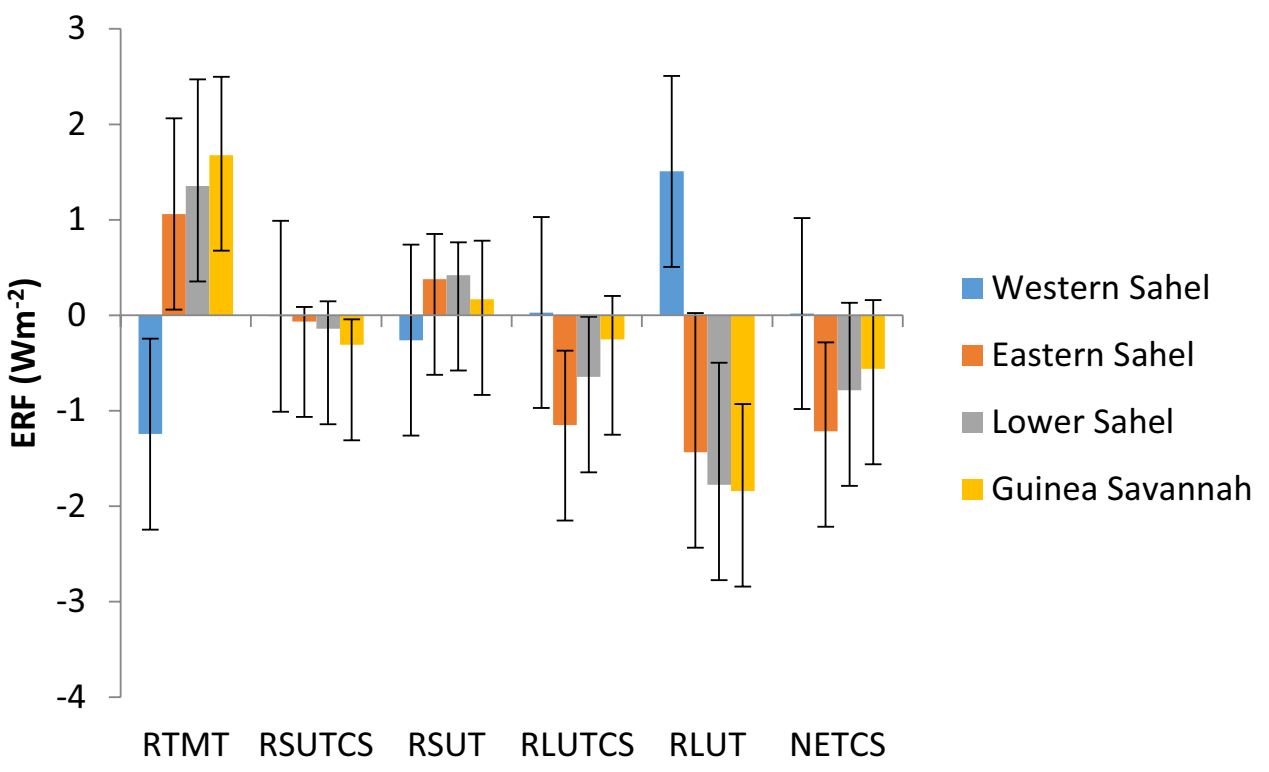

SN Applied Sciences A SPRINGER NATURE journa 
(a) RCP4.5-HIST DTEMP

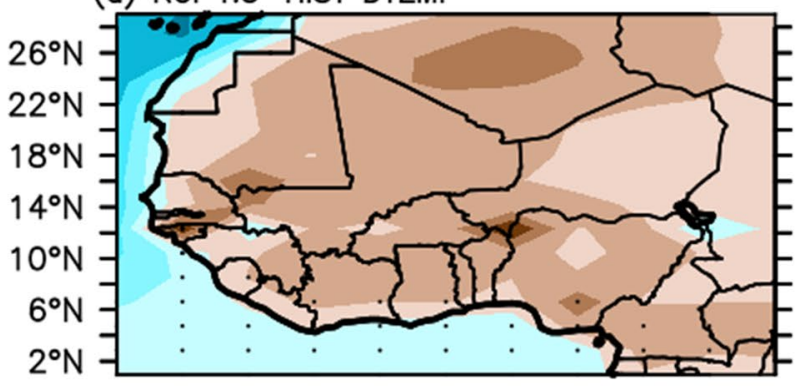

(c) HIST DPRE

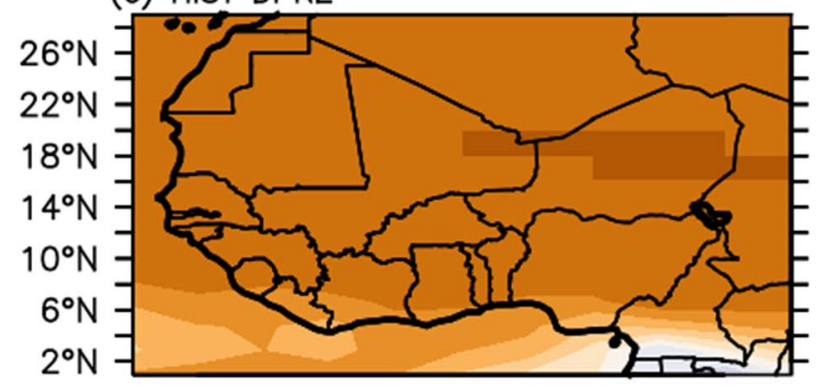

(e) RCP4.5-HIST DPRE
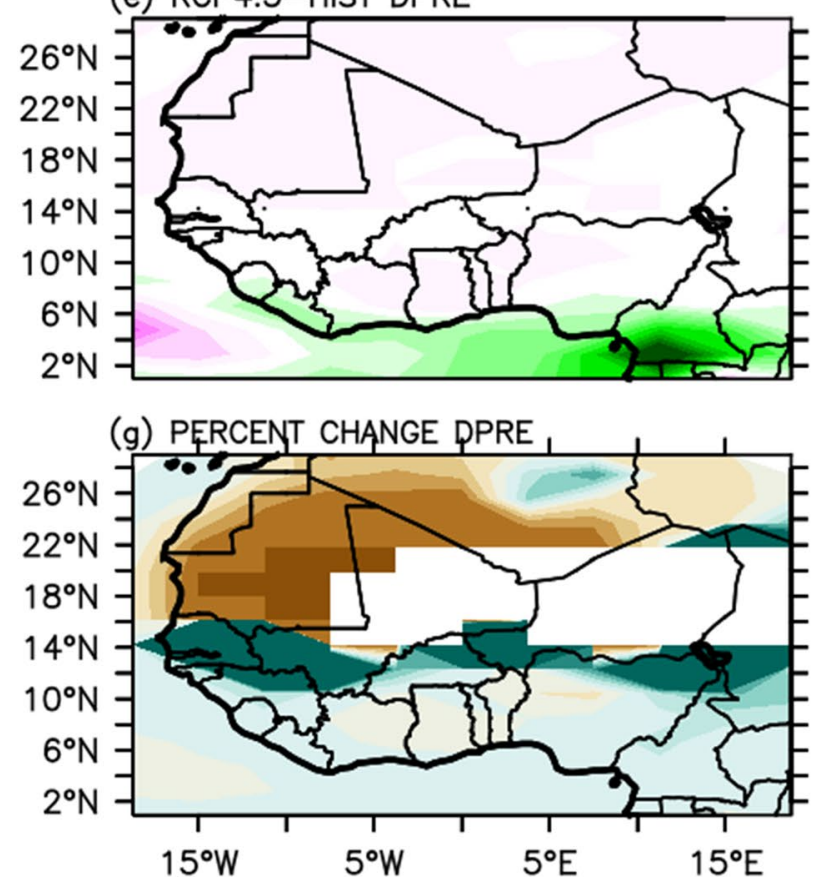

Fig. 3 Projected changes in temperature for a dry season, $\mathbf{b}$ wet season, historical precipitation ( $\mathrm{mm} /$ day) for c dry season, $\mathbf{d}$ wet season; projected change in precipitation for e dry season, $\mathbf{f}$ wet season; and percentage change in precipitation $\mathbf{g}$ dry season, $\mathbf{h}$ wet

warming above 2 standard deviations from the 1986 to 2005 temperature climatology is projected from the coastal areas up to $16^{\circ} \mathrm{N}$ during the wet season (Fig. 3b).

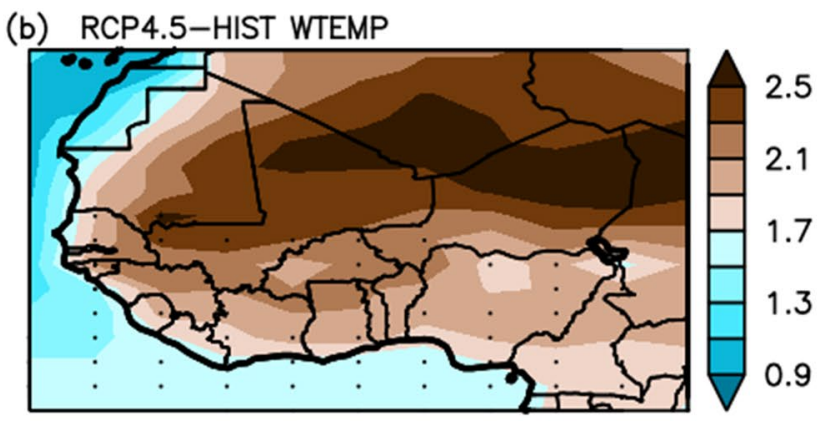

(d) HIST WPRE

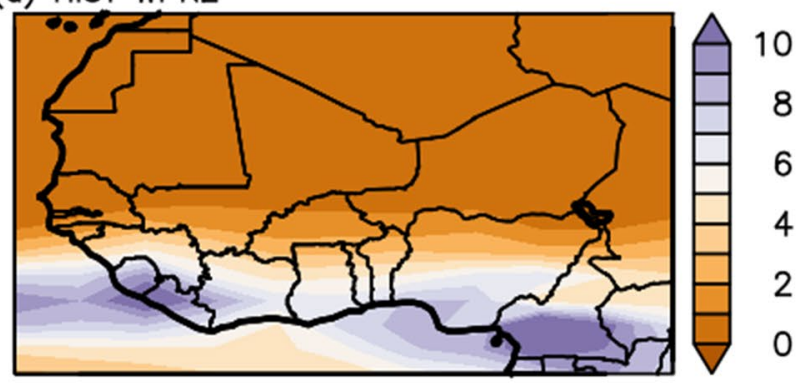

(f) RCP4.5-HIST WPRE
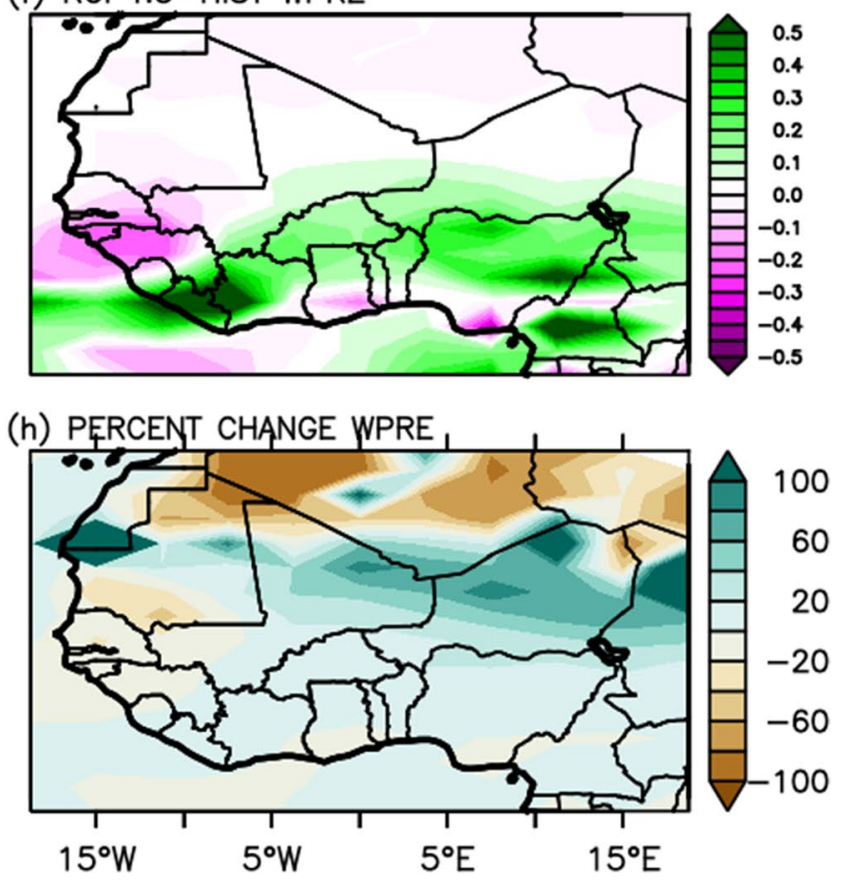

season over West Africa. Significant change at 5\% level is shown as dots overlay on projected temperature $(\mathbf{a}, \mathbf{b})$ and precipitation $(\mathbf{e}, \mathbf{f})$ changes

\subsubsection{Precipitation (no geoengineering) projection}

Historical precipitation climatology (1986-2005) during the dry season is within 0 and $6 \mathrm{~mm} /$ day with highest 
precipitation at the southern ocean and coast (Fig. 3c). Similar spatial pattern of precipitation persist during the wet season with precipitation above $10 \mathrm{~mm} /$ day (Fig. 3d). Wetness is projected at the central and eastern Sahel and generally at the southern ocean and coast (Ivory Coast, Liberia and Cameroon), but significant wetness is only at the Sahel $\left(14-15^{\circ} \mathrm{N}\right)$, everywhere else in the domain would be dryer (Fig. 3e). The area with projected wetness falls within the area with projected significant warming (Fig. 3a, $b, e, f)$.

From the southern ocean to $10^{\circ} \mathrm{N}, 0-20 \%$ increase in precipitation is projected during the dry season. At $14^{\circ} \mathrm{N}$, there is more than $100 \%$ increase in precipitation. From $16^{\circ} \mathrm{N}$ and above, about $100 \%$ reduction in precipitation is projected. Undefined $\%$ change is projected between $3^{\circ} \mathrm{W}$ and $19^{\circ} \mathrm{E}$ from 14 to $20^{\circ} \mathrm{N}$ as a result of division by $0 \mathrm{~mm} /$ day precipitation in the dry season (Fig. $3 \mathrm{~g}$ ).

During the wet season of the RCP 4.5 scenario, wetness is simulated at the coast and land areas below $14^{\circ} \mathrm{N}$, while dryness is simulated above $16^{\circ} \mathrm{N}$. Liberia, western Ivory Coast and southern Cameroon are projected to have the highest and spatially extended wetness (Fig. 3f). Simulated precipitation change is within 2 standard deviations of the 1986-2005 precipitation climatology. Significant wetness is simulated only at Western Sahara during the wet season (Fig. 3f).

Precipitation increases generally up to $20 \%$ from 0 to $14^{\circ} \mathrm{N}$, and precipitation increases up to $80 \%$ between 16 and $22^{\circ} \mathrm{N}$. Reduction of up to $20-80 \%$ is projected above $24^{\circ} \mathrm{N}$ during the wet season (Fig. $3 \mathrm{~h}$ ). This dryness can be associated with the high warming at the area leading to more evaporation than precipitation which enhances drought.

The RCP4.5 increases warming towards the end of the century with respect to historical temperature simulation during both dry and wet seasons as expected ([27]; Fig. S1). Dryness increases at the coast during the wet season in response to warming. This is in line with the findings of Cong and Brady [28] where negative correlation exists between temperature and precipitation during specific months (April to July and September). Area of significant wetness during the dry season reduces greatly towards the end of twenty-first century (Fig. S1). Area of percentage reduction in precipitation spreads at the northern part of the domain $\left(18-29^{\circ} \mathrm{N}\right)$ during the wet season, while the reverse is the case during the dry season (Fig. S1).

\subsection{Climate response to SSCE}

In this section, the impacts of $\mathrm{G} 5$ on the warming projected in the RCP4.5 scenario and the projected changes in precipitation patterns in the RCP4.5 scenario are presented.

\subsubsection{Near-surface air temperature responses to $\mathrm{G} 5$ (GeoMIP G5-RCP 4.5 Scenario)}

In the dry season, G5 is capable of reducing the projected increase in temperature in the RCP4.5 scenario. Cooling prevails in virtually every country in the domain (Fig. 4a) with magnitude of cooling ranging between 0 and $1.2 \mathrm{~K}$. Temperature reduction of $1.2 \mathrm{~K}$ would increase human comfort and would be suitable for crop development $[29,30]$.

In the wet season, G5 experiment also reduces the temperature increase simulated in the RCP 4.5 scenario. Cooling is achieved in every country in the domain (Fig. 4b). Magnitude of the cooling is higher during the wet season; it ranges between 0.4 and $1.2^{\circ} \mathrm{C}$. Significant cooling with respect to preindustrial internal variability is simulated only between the southern ocean and coast $\left(2\right.$ and $\left.6^{\circ} \mathrm{N}\right)$ during the dry season (Fig. 4a). The significant temperature reduction spatially shifts northward $\left(4-8^{\circ} \mathrm{N}\right)$ during the wet season (Fig. $\left.4 \mathrm{~b}\right)$. The spatial location of the significant cooling could be as a result of closeness to the region of application of the sea salt. However, the northward shift in the location of significant cooling could be associated with heating/warming at the tropical ocean, necessary for convection, cloud development and subsequent rainfall during the wet season.

\subsubsection{Precipitation responses to GeoMIP G5 (GeoMIP G5- RCP 4.5 scenario)}

In the dry season, precipitation responds positively to G5 generally at the southern part of the domain between 0 and $10^{\circ} \mathrm{N}$ due to its closeness to the ocean, where cooling is significant. The temperature reduction results in increase in precipitation, which eventually leads to wetness in the area. This is part of the interdependence between temperature and precipitation reported in Cong and Brady [28] that temperature and precipitation may have negative correlation. The G5 induced dryness is simulated to be highest at north-eastern Niger, northern Chad and part of Algeria, Senegal, Gambia, Guinea, Guinea Bissau Sierra Lone, Chad and Libya, while southern Ivory Coast and Ghana would have highest magnitude of wetness on land (Fig. 4e). Significant change during dry season is simulated between 14 and $22^{\circ} \mathrm{N}$.

The $\mathrm{G} 5$ simulates wetness during the wet season over West Africa from $6^{\circ} \mathrm{N}$ and above, with highest magnitude of wetness up to $10^{\circ} \mathrm{N}$. Dryness is simulated below $6^{\circ} \mathrm{N}$ (Fig. 4f). The area with significant cooling during the wet season is also the area with more wetness. 


\section{(a) G5-RCP4.5 DTEMP}

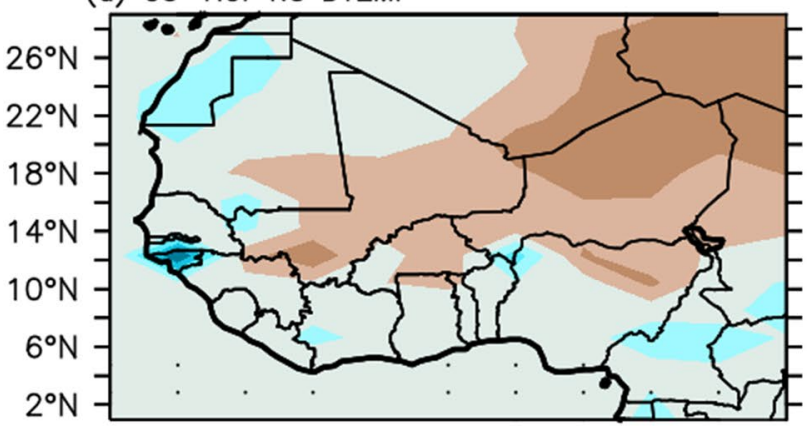

(c) G5-RCP4.5 DPRE

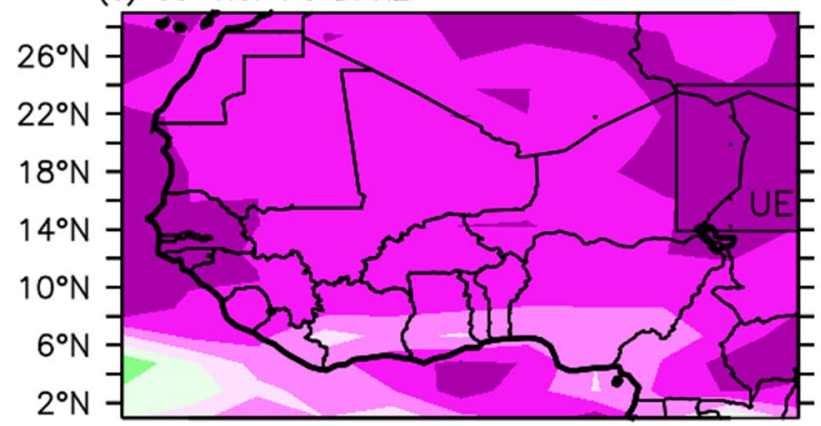

(e) PERCENT CHANGE DPRE

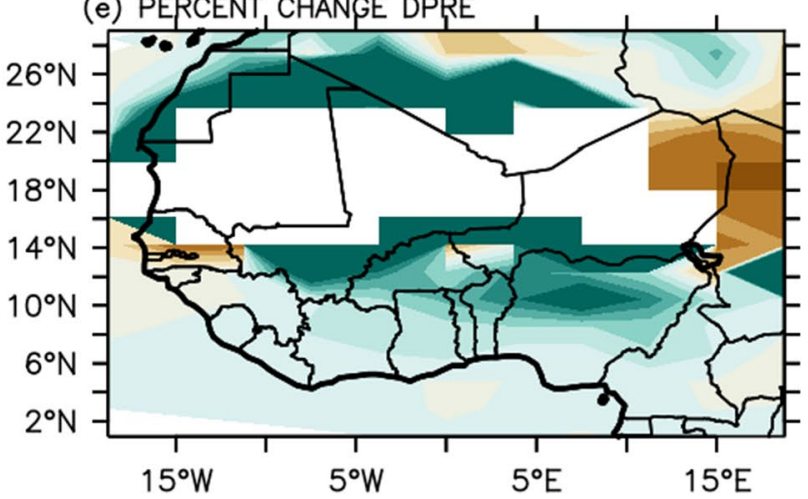

Fig. 4 Response of the climate to $\mathrm{G} 5$ for temperature in a dry season, $\mathbf{b}$ wet season, for precipitation in $\mathbf{c}$ dry season, $\mathbf{d}$ wet season for percentage change in precipitation, e dry season and $\mathbf{f}$ wet season. Significant change at $5 \%$ level is shown as dot overlay.

The wetness can be associated with lower evaporation than precipitation, which gives resultant wetness. There is no significant change in $\mathrm{G} 5$ simulated precipitation with respect to $\mathrm{RCP} 4.5$ during wet season.

During the dry season, undefined percentage change in precipitation is found at the Sahel as a result of division by zero $(0 \mathrm{~mm} /$ day precipitation). At the Sahel, precipitation increase is above $100 \%$, at the Guinea coast and Savannah; the increase in precipitation is between 40 and $60 \%$. Precipitation reduction is simulated at southern Senegal, with up to $100 \%$ reduction at north-eastern Niger and northern Chad. During wet season, precipitation increase ranges

\section{(b) G5-RCP4.5 WTEMP}

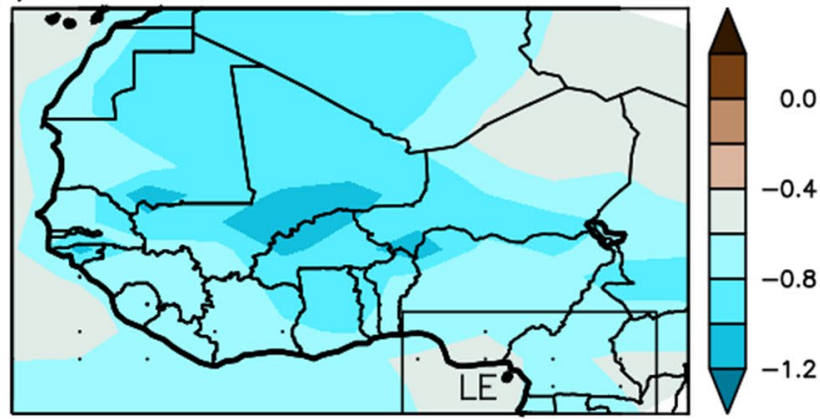

(d) G5-RCP4.5 WPRE

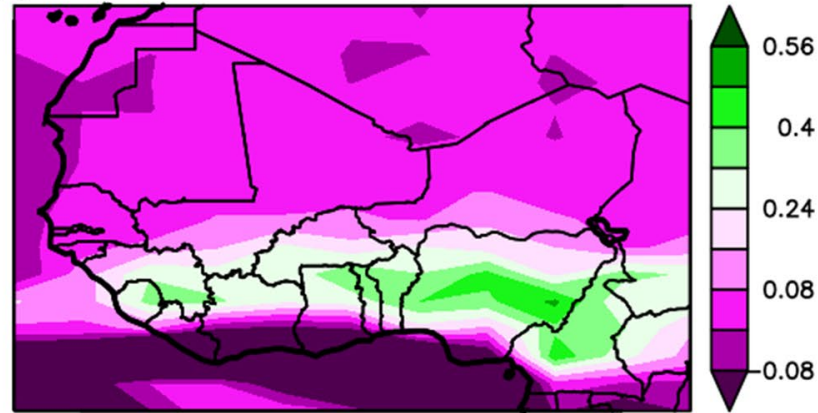

(f) PERCENT CHANGE WPRE

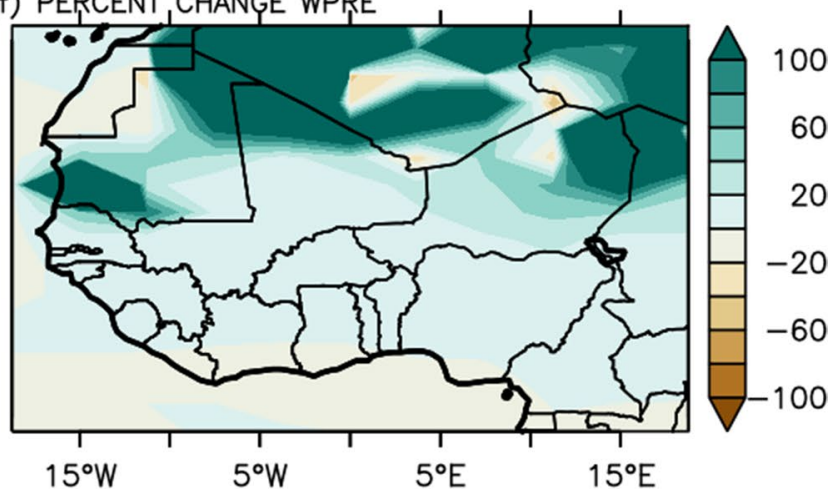

The selected areas for time series analysis LE represents lower east region, while UE represents upper east region shown on panels (b) and $(\mathbf{c})$, respectively

between 20 and above $100 \%$ on the land with highest \% increase at the Sahel and Sahara (Fig. 4e, f).

Figure 5 shows northward moisture movement from G5 and RCP4.5 in the atmospheric column (Fig. 5a, c, e) and simulated height-latitude zonal wind over the study area $\left(-19: 19^{\circ} \mathrm{E}\right)$ from $\mathrm{G} 5$ and RCP4.5 (Fig. 5b, d, f). In RCP4.5, positive northward moisture movement is simulated up to $13^{\circ} \mathrm{N}$ with undulating shape, which depicts the ITCZ position. Above $13^{\circ} \mathrm{N}$ is negative northward moisture movement, however, the north-western area of the domain has positive northward moisture movement (Fig. 5a). Similar spatial pattern of northward moisture 


\section{(a) qv RCP4.5}

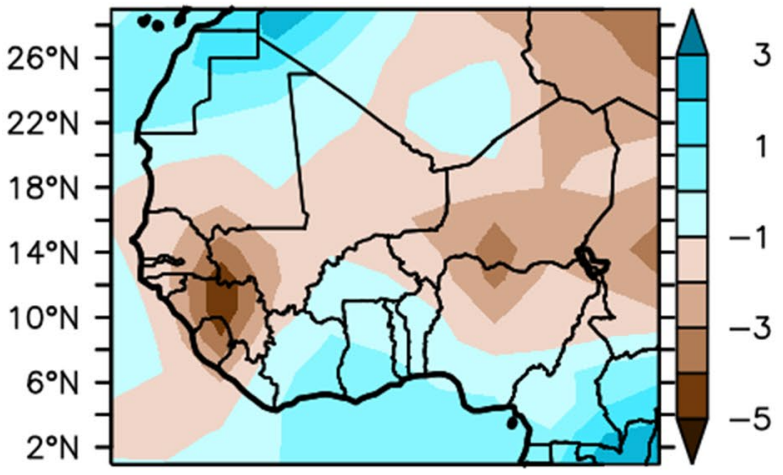

(b) qv G5
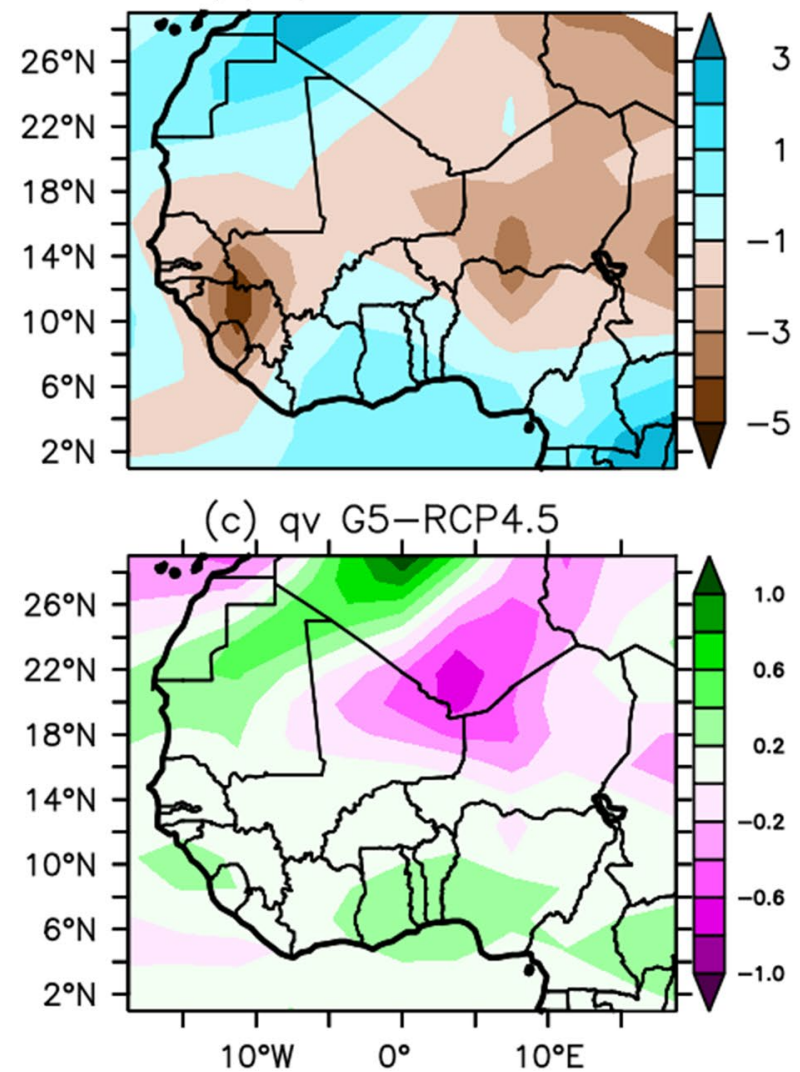

\section{(d) 4 RCP 4.5}

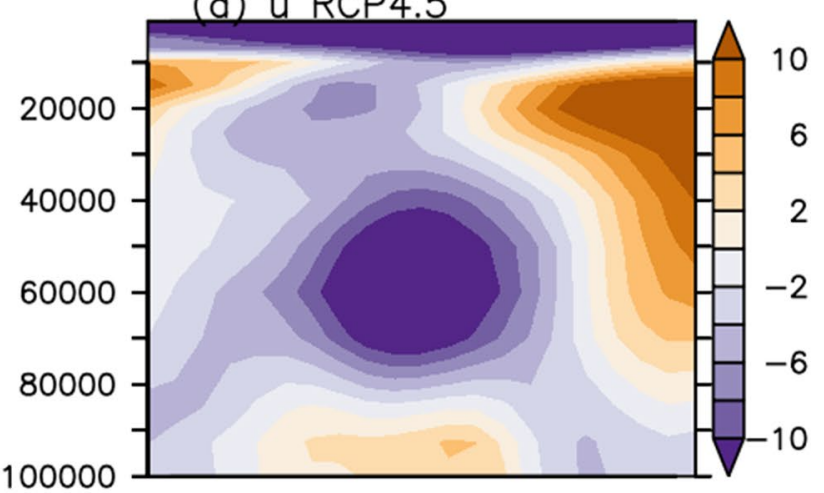

(e) U G5
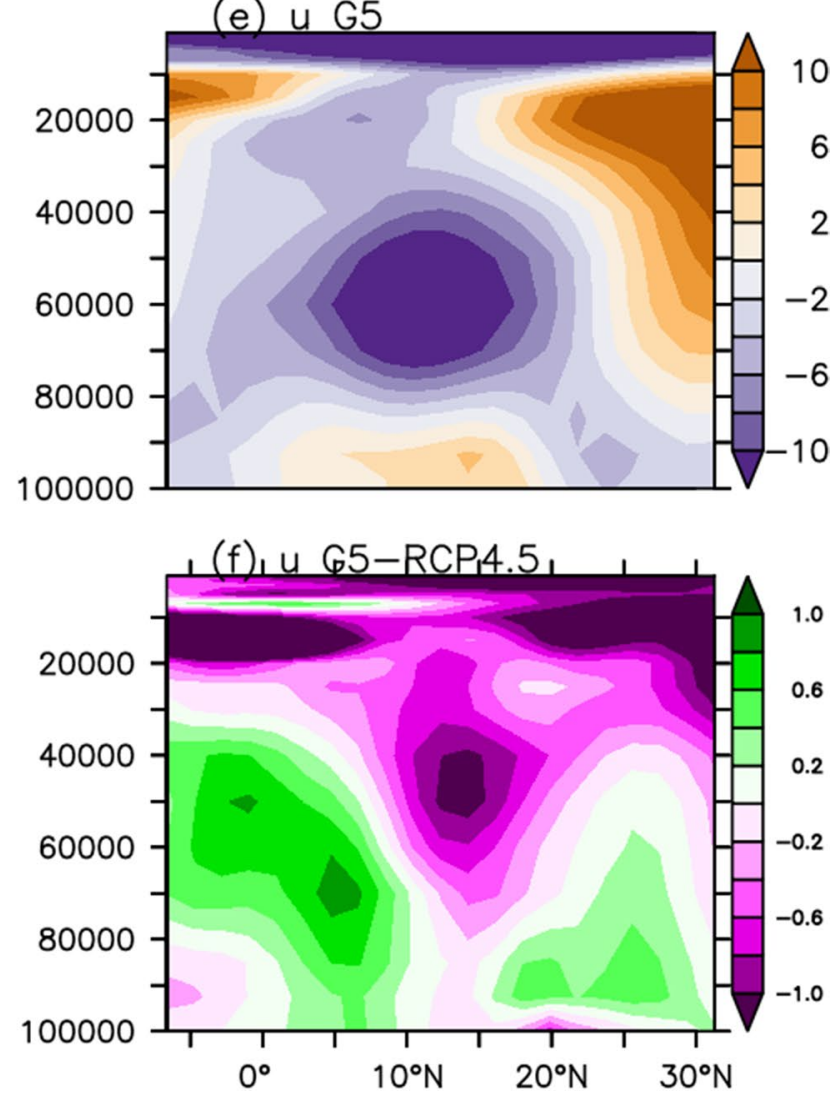

Fig. 5 Northward movement of moisture for a RCP4.5, b G5, c G5-RCP4.5 and vertical profile zonally averaged ( -19 to $\left.19^{\circ} \mathrm{E}\right)$ zonal wind for d RCP4.5, e G5, f G5-RCP4.5 over West Africa

movement is simulated in G5, but the ITCZ level moves further north (Fig. 5b). The difference between $\mathrm{G} 5$ and RCP4.5 (G5-RCP4.5) reveals more moisture at the southern land areas up to $18^{\circ} \mathrm{N}$. The north-western area of the domain also has more moisture having SW-NE orientation from south Western Sahara and northern Mauritania to northern Algeria. More northward moisture movement with G5 (Fig. 5a, C, e) should favour more rainfall at the land areas between 4 and $10^{\circ} \mathrm{N}$. This corroborates the wetness simulated at the area (Fig. 4c, d). The increased northward moisture movement simulated at south Western Sahara, northern Mauritania to Algeria with SW-NE orientation (Fig. 5b) lends support to the wetness simulated at the area (Fig. 4c-f).

The Tropical Easterly Jet (TEJ) and the Africa Easterly Jet (AEJ) centres are shown in Fig. 5b, d at 100 and $600 \mathrm{hPa}$, respectively. The location of AEJ is usually dry [31], while strong baroclinic instability occurs at regions 
below the AEJ (Nicholson 2008) leading to wetness. The latitudinal locations of the TEJ and AEJ core are similar in RCP4.5 and G5 simulations (Fig. 5b, d). The simulated difference between G5 and RCP4.5 zonal wind (G5-RCP4.5) shows westerly at the lower troposphere to the midtroposphere between 2 and $9^{\circ} \mathrm{N}$ and $18-29^{\circ} \mathrm{N}$, which should support more rainfall at such latitudes (Fig. $5 f$ ). Easterly wind is stronger at $15^{\circ} \mathrm{N}$ at the midlatitude (580-350 $\mathrm{hPa}$ ). Increased precipitation is expected at latitudes below $15^{\circ} \mathrm{N}$ and also at latitudes with westerly wind. This corroborated in the simulated wetness in these areas (Fig. 4c-f).

Analysis of the climate response to the withdrawal of sea salt injection after 2070 shows reduced and insignificant cooling over West Africa (Fig. S2). This is expected since the amount of sea salt in the marine clouds has greatly reduced its effect on the weather and climate has to reduce. Dryness and reduced wetness also prevails during both seasons during this period especially at the ocean and coast where sea salt is usually injected. The area responds greatly to the withdrawal of the sea salt (Fig. S2). At the Sahel, however, the area with significant dryness during sea salt injection in dry season ceases to have significant dryness (Fig. 4c, Fig. s2c), while there exists more area with significant wetness at the Sahel after the withdrawal of the sea salt injection. The withdrawal of sea salt after 50 years does not cause any wide spread significant warming or dryness over West Africa.

\subsection{Effectiveness}

In this section, the framework earlier mentioned in Sect. 2.2.3 is used to study the effectiveness of G5 in reducing the warming projected in the RCP4.5 scenario by analysing near-surface air temperature response. Precipitation is also analysed for effectiveness of G5. This is done by comparing simulations of near-surface air temperature and precipitation from G5 with that of the 1986-2005 climatology. The results are finally compared to the climate response to G5 (G5-RCP4.5).

\subsubsection{Effectiveness of $\mathrm{G} 5$ in temperature change}

In the dry season, the G5 is generally effective over land since the simulated change is within 2 standard deviations in the historical temperature (Fig. 6a). However, it is damaging at the southern Ocean and coasts (Figs. 4a, 6a), i.e., the simulated change is outside \pm 2 STDs in historical temperature and the $\mathrm{G} 5$ temperature is closer to RCP4.5 than historical temperature. A similar pattern of effectiveness is simulated for the wet season (Figs. 4b, 6b).

\subsubsection{Effectiveness of G5 in precipitation change}

In the dry season, G5 simulates wetness with respect to historical precipitation everywhere in West Africa and it is effective everywhere on the domain except at the SW-NE-oriented part of the Sahel from 10 to $22^{\circ} \mathrm{N}$ and $7^{\circ} \mathrm{W}$ to $7^{\circ} \mathrm{E}$ where $\mathrm{G} 5$ is damaging for precipitation because the difference with respect to historical precipitation is outside \pm 2 STD and the G5 precipitation is closer to the RCP4.5 precipitation than the historical precipitation (Figs. 4c, 6c). The $\mathrm{G} 5$ is effective in precipitation simulation also at the southern coast, where it is damaging for temperature simulation (Fig. 6a-d).

With the use of G5 in the wet season, dryness is simulated at the southern coast and inland areas up to $8^{\circ} \mathrm{N}$, everywhere else in the domain is expected to be wetter with respect to historical precipitation (Fig. 6). Areas with high temperature and close to the ocean would have more rainfall and vice versa (Fig. 6b, d). The use of G5 is damaging to precipitation during the wet season only at the Western Sahara but effective at every other area in the domain (Fig. $6 \mathrm{~d}$ ). The damaging precipitation tilts towards wetness in both the dry and wet seasons (dotted areas in Fig. 6c, d). The changes in G5 precipitation cannot have negative impact on water resources since there is mostly precipitation increase and the areas where there is reduced precipitation the reduction are mostly not significant.

The period after the withdrawal of sea salt injection shows similar effectiveness of G5 experiment on temperature and precipitation over West Africa (Fig. S3).

Areas with significant temperature (lower east, LE) and precipitation (upper east, UE) changes in response to $\mathrm{G} 5$ are selected (Fig. 4b, c) for the time series analysis. Averaging the whole domain would even out the positive and negative changes. Both the LE and UE are used for temperature and precipitation series. At the UE, temperature increases towards the end of the experiment in RCP4.5 and G5 but reduces at the mid-period in G5. Precipitation increases at the start of $\mathrm{G} 5$ and reduces at the end. Precipitation increases towards the end of the century for RCP4.5 at the upper east. At the lower east region, also temperature increases towards the end of the RCP 4.5 experiment, while it increases towards the end of the experiment in $\mathrm{G} 5$ but reduces at the midperiod of the experiment when the impact of $\mathrm{G} 5$ is felt. It reduces afterwards as a result of the withdrawal of the sea salt.G5 precipitation is higher at the start of the experiment and low at the end of the experiment. In the RCP4.5 projection, precipitation is low at the start of the experiment, but higher at the end of the experiment (Fig. 7). 
(a) G5-HIST DTEMP

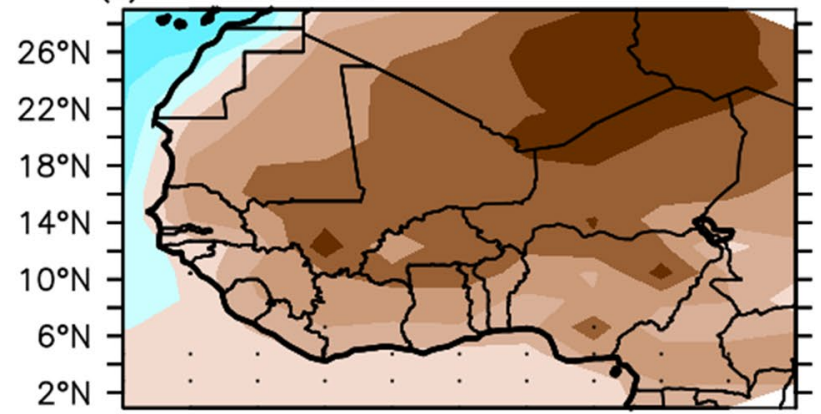

(c) G5-HIST DPRE

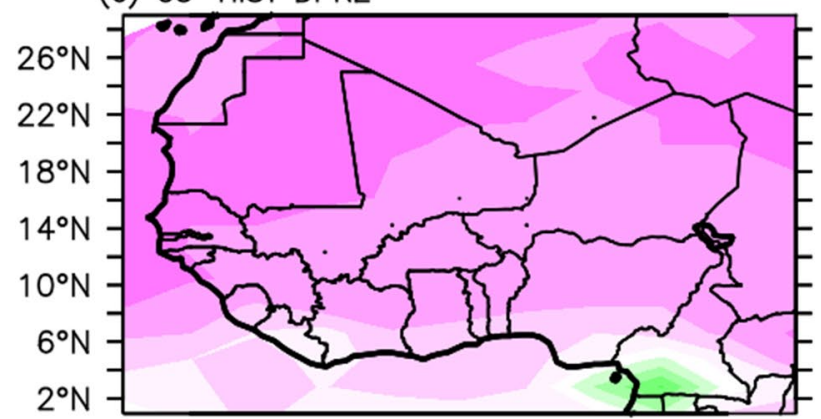

(e) PERCENT CHANGE DPRE

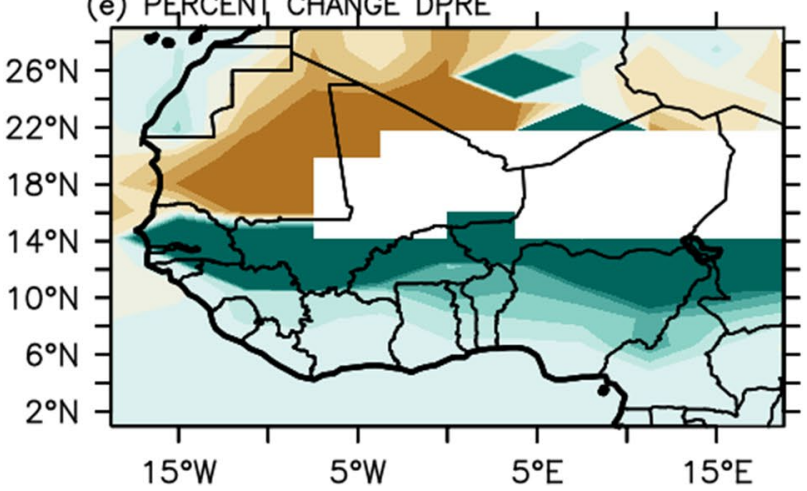

Fig. 6 Difference between G5 and historical simulations for a temperature in dry season, $\mathbf{b}$ temperature in wet season, $\mathbf{c}$ precipitation in dry season, $\mathbf{d}$ precipitation in wet season and percentage differ-

\section{Conclusion and recommendation}

The radiative forcing, impact and effectiveness of $\mathrm{G} 5$ on the climate are analysed using simulation output from the Earth System Model IPSL-CM5A-LR.

Net downward flux and top of atmosphere outgoing shortwave radiation have negative forcing only at the western Sahel. This area is very close to the tropical marine area, where the sea salt injection is done.

Without geoengineering, warming is projected virtually everywhere in the domain when compared to the historical climatology, Sahel is part of the areas projected to have strong warming. Precipitation patterns would be highly affected by the warming, with most part of the domain (b) G5-HIST WTEMP

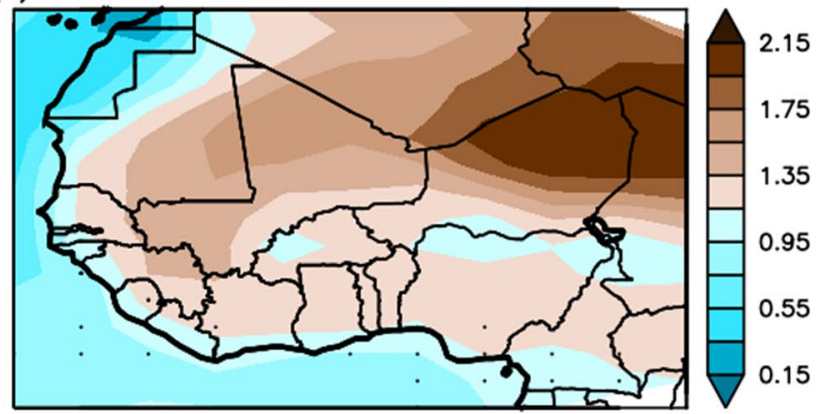

(d) G5-HIST WPRE

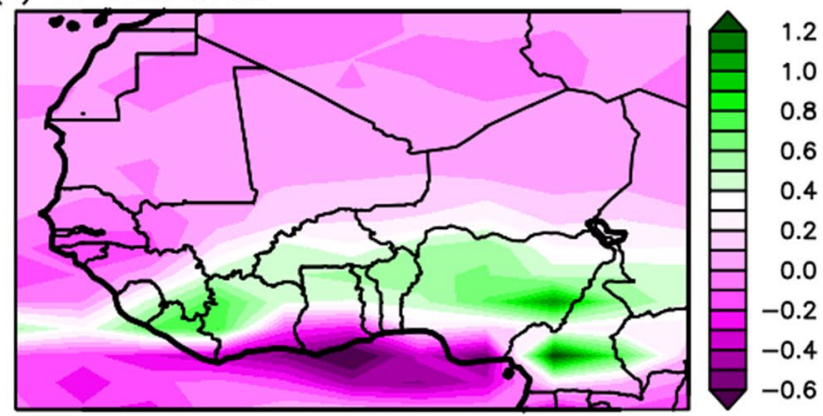

(f) PERCENT, CHANGE WPRE

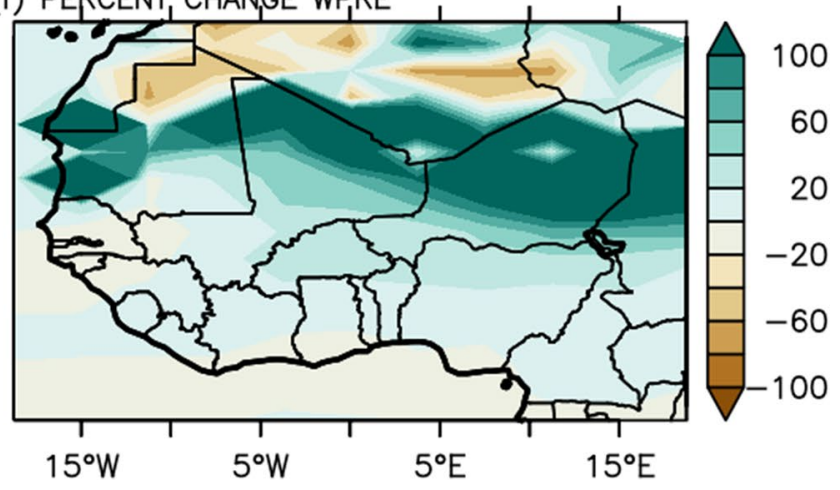

ence for precipitation in e dry season and $\mathbf{f}$ wet season. Significant change at $5 \%$ level is shown as dot overlay

becoming wetter. Southern land area has the highest increase in precipitation; percentage increase in precipitation is projected to be higher in the dry season at the Sahel than in the wet season.

G5 experiment simulates cooler climate over West Africa irrespective of the season with respect to RCP4.5 temperature. Significant cooling with respect to preindustrial variability is simulated at the southern ocean and coastal areas up to the Savannah. G5 generally led to wetness over West Africa. However, insignificant dryness prevails at the southern ocean and coast during the wet season. Significant dryness occurs only at the eastern Sahel during the dry season, and this is the area with least cooling $(\sim 0 \mathrm{~K})$. The relatively higher temperature in this 
(a) Temp Upper East

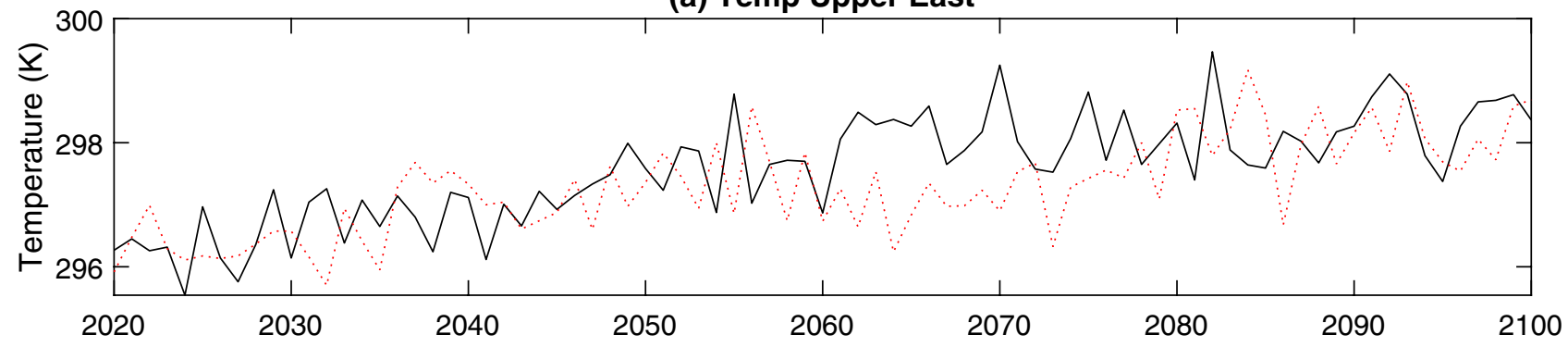

(b) Temp Lower East

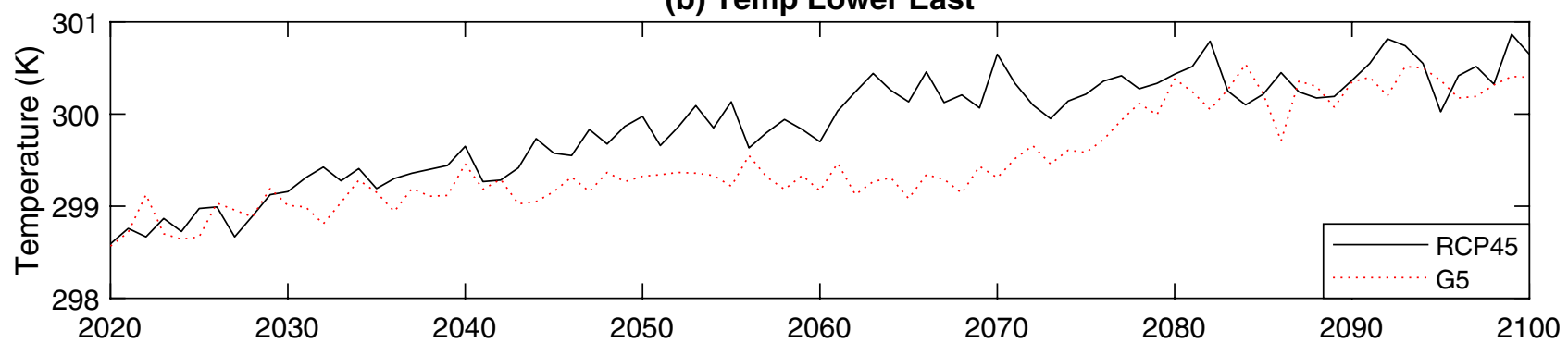

(c) Precip Upper East

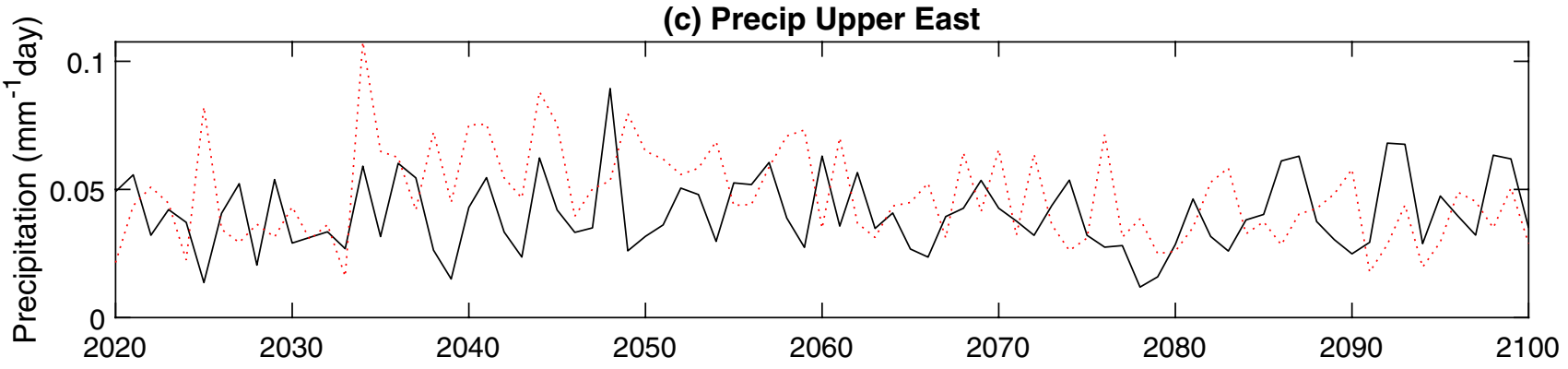

(d) Precip Lower East

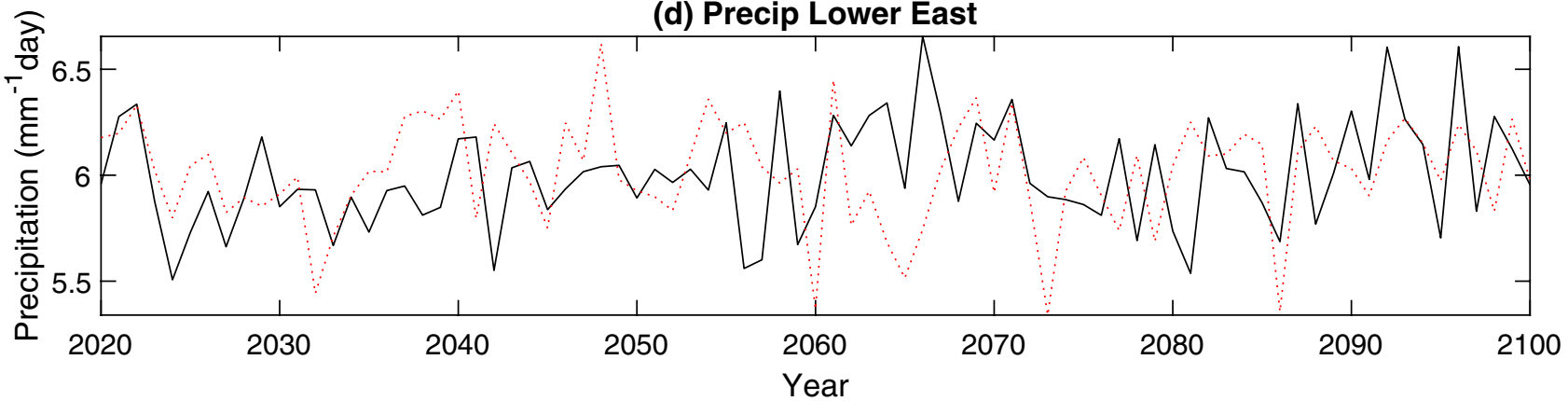

Fig. 7 Time series of temperature at $\mathbf{a}$ upper east and $\mathbf{b}$ lower east regions; precipitation at $\mathbf{c}$ upper east and $\mathbf{d}$ lower east regions. The two regions have substantial changes in opposite directions for temperature and precipitation

area leads to significant precipitation reduction especially in the dry season.

The G5 is effective in reducing the projected warming in RCP4.5 by about $1.2 \mathrm{~K}$ for most countries in the domain, but has a damaging effect on temperature at the southern ocean and coast based on significant change with respect to historical temperature that tilts towards change with respect to RCP4.5. Temperature reduction of $1.2 \mathrm{~K}$ would increase human comfort and is suitable for crop development. The $\mathrm{G} 5$ is also effective in increasing precipitation over West Africa except at some part of southern ocean and coast during the wet season. The G5 is damaging to precipitation at some part of the Sahel, and the change is also wetness. Therefore, G5 cannot affect water resources negatively over West Africa.

The G5 experiment suggests a promising solar radiation management method that can be applied to combat warming over West Africa since it effectively cools most 
land areas of the West African domain. The area with damaging temperature reduction also does not have damaging precipitation change. Furthermore, the $\mathrm{G} 5$ experiment is effective in precipitation increase over the whole of West Africa except for a small area with insignificant precipitation reduction at the southern ocean and coast during the wet season. It cannot affect water security negatively. The damaging precipitation increase at the Sahel can be dealt with by adequate adaptation strategy for more rainfall in that area.

Acknowledgements The authors are grateful to the coordinators of the Geoengineering Model Intercomparison Project and the Institute Pierre Simon Laplace ESM (IPSL-CM5A) for the release of the G5 model output for use in this study.

Author contributions The corresponding author and the second author started the work and completed the work together. The corresponding author is the master minder of the research that continued to teach the second author and give instructions, data and methodology for the second author to carry out. She also carried out the perfection of the paper work.

Funding No funding was received for this study.

Code availability Not applicable.

Availability of data and material All the data used in this study are available at: https://vesg.ipsl.upmc.fr/threads/catalog/esgcet/4/ geomip.output.IPSL.IPSL-CM5A-LR.G5.mon.atmos.Amon.r1i1p 1.v20130428

\section{Compliance with ethical standards}

Conflict of interest On behalf of all authors, the corresponding author states that there is no conflict of interest.

Open Access This article is licensed under a Creative Commons Attribution 4.0 International License, which permits use, sharing, adaptation, distribution and reproduction in any medium or format, as long as you give appropriate credit to the original author(s) and the source, provide a link to the Creative Commons licence, and indicate if changes were made. The images or other third party material in this article are included in the article's Creative Commons licence, unless indicated otherwise in a credit line to the material. If material is not included in the article's Creative Commons licence and your intended use is not permitted by statutory regulation or exceeds the permitted use, you will need to obtain permission directly from the copyright holder. To view a copy of this licence, visit http://creativecommons .org/licenses/by/4.0/.

\section{References}

1. Schaltegger S, Csutora M, Huisingh D (2011) Climate costs and benefits: new challenges for corporate accounting and management. J Clean Prod 19:1141-1143

2. Niang I, Ruppel OC, Abdrabo MA, Essel A, Lennard C, Padgham J, Urquhart P (2014) Africa. In: Climate change. Impacts, adaptation, and vulnerability. Part: Regional aspects. Contribution of Working Group II to the Fifth Assessment Report of the
Intergovernmental Panel on Climate change. Cambridge University Press, Cambridge

3. Mukherjee S, Aadher S, Stone D, Mishra V (2018) Increase in extreme precipitation events under anthropogenic warming in India. Weather Clim Extremes 20:45-53

4. Adeniyi MO (2016) The consequences of the IPCC AR5 RCPs 4.5 and 8.5 climate change scenarios on precipitation in West Africa. Clim Change 139:245-263. https://doi.org/10.1007/s1058 4-016-1774-2

5. WAHO (2009) Impact of climate change on health and current policy responses in West Africa. www.thecommonwealh. org/1files/190387/FileName/WAHO_2009.pdf. Accessed 2nd Dec 2020

6. Ezeife ND (2014) Projected impact of global warming on West Africa: Case for regional and transnational adaptive measures. Ann Surv Int Compar Law 20(1):9

7. ACMEN (2007) IPCC summary for policy makers. Fact sheet, Climate change Africa-what is at stake? Excerpts from IPCC reports, the convention, and BAP compiled by ACMEN Secretariat. https://www.ipcc.ch/pdf/assessment-report/ar4/wg2/ ar4_wg2_full_report.pdf. Accessed 2nd Dec, 2020

8. Alterskjær $\mathrm{K}$, Kristjánsson JE, Boucher $\mathrm{O}$, Muri H, Niemeier $\mathrm{U}$, Schmidt H, Schulz M, Timmreck C (2013) Sea-salt injections into the low-latitude marine boundary layer: the transient response in three Earth system models. J Geophys Res Atmos. https://doi. org/10.1002/2013JD020432

9. Niemeier U, Schmidt H, Alterskjær K, Kristjánsson JE (2013) Solar irradiance reduction via climate engineering: Impact of different techniques on the energy balance and the hydrological cycle. J Geophys Res Atmos 118:11905-11917. https://doi. org/10.1002/2013JD020445

10. Albrecht BA (1989) Aerosols, cloud microphysics, and fractional cloudiness. Science 245:1227-1230

11. Kravitz B, Robock A, Boucher O, Schmidt H, Taylor KE, Stenchikov G, Schulz M (2011) The geoengineering model intercompresssion project (GeoMIP). Perspectives 463:746-756. https://doi. org/10.1002/asl.316

12. Moss RH, Edmonds JA, Hibbard KA, Manning MR, Rose SK, van Vuuren DP, Carter TR, Emori S, Kainuma M, Kram T, MeehI GA, Mitchell JFB, Nakicenovic N, Riahi K, Smith SJ, Stouffer RJ, Thomson AM, Weyant JP, Wilbanks TJ (2010) The next generation of scenarios for climate change research and assessment. Nature 463:747-756. https://doi.org/10.1038/nature08823

13. Kravitz B, Robock A, Tilmes S, Boucher O, English JM, Irvine PJ, Jones A, Lawrence MG, MacCraken M, Muri H, Moore JC, Niemeier U, Phipps SJ, Sillmann J, Storelvmo T, Wang H, Watanabe $S$ (2015) The geoengineering model intercomparison project phase 6 (GeoMIP6) simulation design and preliminary results. Geosci Model Dev 8:3379-3392. https://doi.org/10.5194/ gmd-8-3379-2015

14. Smith S-J, Wigley TML (2006) MultiGas forcing stabilization with minicam. Energy J Spec Issue \#3:373-392

15. Clarke LE, Edmonds JA, Jacoby HD, Pitcher H, Reilly JM, Richels $R$ (2007) Scenarios of greenhouse gas emissions and atmospheric concentrations. Sub-report Part A of synthesis and assessment product 2.1. Climate Change Science Program and the Subcommittee on Global Change Research, Washington, DC. 10.1.1.170.6077.dpf

16. Wise $M$, Calvin $K$, Thomson A, Clarke L, Bond-Lamberty B, Sands R, Smith S-J, Janetos A, Edmonds J (2009) Implications of limiting $\mathrm{CO}_{2}$ concentrations for land use and energy. Science 324:1183-1186

17. Dufresne J-L, Foujols M-A, Denvil S, Caubel A, Marti O, Aumont O, Balkanski Y, Bekki S, Bellenger H, Benshila R, Bony S, Bopp L, Braconnot $\mathrm{P}$, Brockmann $\mathrm{P}$, Cadule $\mathrm{P}$, Cheruy F, Codron F, Cozic $A$, Cugent D, de Noblet N, Duvel J-P, Ethé C, Fairhead L, Fichefet 
T, Flavoni S, Friedlingstein P, Grandpeix J-Y, Guez L, Guilyardi $E$, Hauglustaine D, Hourdin F, Idelkadi A, Ghattas J, Joussaume S, Kageyama M, Krinner G, Labetoulle S, Lahellec A, Lefebvre M-P, Lefevre F, Levy C, Li ZX, Lloyd J, Lott F, Madec G, Mancip M, Marchnd M, Masson S, Meurdesoif Y, Mignot J, Musat I, Parouty S, Polcher J, Rio C, Schulz M, Swingedouw D, Szopa S, Talandier C, Terray P, Viovy N, Vuichard N (2013) Climate change projections using the IPSL-CM5 earth system model: from CMIP3 to CMIP5. Clim Dyn 40:2123-2165. https://doi.org/10.1007/s0038 2-012-1636-1

18. Hourdin F, Musat I, Bony S, Braconnot P, Codron F, Dufresne $J L$, Fairhead L, Filiberti MA, Friedlingstein P, Grandpeix JY, Krinner G, LeVan P, Lott F (2006) The LMDZ4 general circulation model: climate performance and sensitivity to parametrized physics with emphasis on tropical convection. Clim Dyn 27(7-8):787-813. https://doi.org/10.1007/ s00,382-006-0158-0

19. Krinner G, Viovy N, de Noblet-Ducoudre N, Ogee J, Polcher J, Friedlingstein P, Ciais P, Sitch S, Prentice I-C (2005) A dynamic global vegetation model for studies of the coupled atmospherebiosphere system. Glob Biogeochem Cycles 19(1):GB1015. https ://doi.org/10.1029/2003GB002199

20. Madec G (2008) NEMO ocean engine. Technical note, IPSL. http://www.nemo-ocean.eu/content/download/11245/56055 /file/NEMObook v32.pdf

21. Fichefet T, Maqueda MA (1997) Sensitivity of a global sea ice model to the treatment of ice thermodynamics and dynamics. J Geophys Res 102(6):12609-12646. https://doi. org/10.1029/97JC00480

22. Aumont $\mathrm{O}$, Bopp L (2006) Globalizing results from ocean in situ iron fertilization studies. Glob Biogeochem Cycles 20(2):2017. https://doi.org/10.1029/2005GB002591

23. Adeniyi MO, Nweke GC (2019) Performance of CMIP5 models in temperature simulation over West Africa. J Niger Assoc Math Phys 49:147-158
24. Zebaze S, Jain S, Salunke P, Shafiq S, Ishra SK (2019) Assessment of CMIP5 multimodel mean for the historical climate of Africa. Atmos Sci Lett 20(8):1. https://doi.org/10.1002/asl.926

25. Gregory JM, Ingram WJ, Palmer MA, Jones GS, Stott PA, Thorpe RB, Lowe JA, Johns TC, Williams KD (2004) A new method for diagnosing radiative forcing and climate sensitivity. Geophys Res Lett 31:L03205. https://doi.org/10.1029/2003GL018747

26. Crook JA, Jackson LS, Osprey SM, Forster PM (2015) A comparison of temperature and precipitation responses to different Earth radiation management geoengineering schemes. J Geophys Res Atmos 120:9352-9373. https://doi.org/10.1002/2015J D023269

27. Collins $M$ et al (2013) Long-term climate change: projections, commitments and irreversibility, in Climate Change 2013: The Physical Science Basis. Contribution of Working Group I to the Fifth Assessment Report of the Intergovernmental Panel on Climate Change, edited by TF Stocker et al. Cambridge University Press, Cambridge, New York

28. Cong R-G, Brady M (2012) The interdependence between rainfall and temperature. Sci World J. https://doi. org/10.1100/2012/405675

29. Kaushal N, Bhandari K, Siddique KHM, Nayyar H (2016) Food crops face risingtemperatures: an overview of responses, and adaptive mechanisms, and approaches to improve heat tolerance. Cogent Food Agric. https://doi.org/10.1080/23311 932.2015.1134380

30. Adeniyi MO (2019) On the Influence of variations in solar irradiance on climate: a case study of West Africa. Earth Syst Environ 3:189-202. https://doi.org/10.1007/s41748-019-00103-2

31. Adeniyi MO (2014) Variability of daily precipitation over Nigeria. Meteorol Atmos Phys 126:161-176. https://doi.org/10.1007/ s00703-014-0340-6

Publisher's Note Springer Nature remains neutral with regard to jurisdictional claims in published maps and institutional affiliations. 